\title{
VÁGÓBÉLYEG GEOMETRIÁJÁNAK HATÁSA A FESZÜLTSÉGEK ELOSZLÁSÁRA
}

\section{THE STUDY OF STRESS DISTRIBUTION DEPENDING ON THE GEOMETRY OF A PUNCHING TOOL}

\author{
Péter Attila \\ Sapientia Erdélyi Magyar Tudományegyetem, Müszaki és Humán Tudományok Kar, \\ Gépészmérnöki Tanszék. Cím: Románia, Marosvásárhely/Koronka, Segesvári út 1C \\ Telefon / Fax: +40-265-206210/+40-265-206211.attilapeter22@gmail.com
}

\begin{abstract}
This paper presents a FEM analysis of the stress and deformation distribution in the body of a puncheon used in perforating or offcutting cold forming devices. The study focuses on the stress distribution in dependence with the tool fillet radius on the punching contour and the width of the bridge. The model uses the Stress Analyzis module of the Autocad Inventor software. The input of the model is given by the thickness of the metal sheet, the geometry and mechanical properties of the puncheon and the punching force. The program outputs the optimal fillet radius and the minimal bridge width.

Keywords: geometry, punching tool, stress analyzis.

\section{Összefoglalás}

A dolgozat a hidegalakítással történő kivágó-lyukasztó bélyegek működés során fellépő terhelését vizsgálja, az anyagpalló szélessége és a sarkak lekerekítési sugarának függvényében. A vizsgálat az Autocad Inventor Stress Analyzis program segítségével végeselem-módszerrel történik. A bevitt adatok alapján (munkadarab lemez vastagsága, vágóbélyeg mechanikai tulajdonságai, vágóerő) meghatározható a minimális pallószélesség és az optimális sarokkerekítés. Minimális pallószélesség használatakor anyag és befektetett energia takarítható meg ezáltal optimalizálható a hidegalakító szerszám müködése.
\end{abstract}

Kulcsszavak: geometria, kivágó szerszám, feszültség vizsgálat.

\section{Bevezetés}

Lemezből préselt tárgyakat nagyon sok helyen használunk mind a mindennapi életben (kanál, villa, alátétek) mind az iparban (ácsok által használt kötőelemek, elektronikában). Hideg préselés során a megmunkálni kívánt lemezt a vágó- illetve hajlító bélyegek segítségével alakítsuk a kívánt alakra. A bélyegek geometriája kiemelkedő szerepet tölt be, hogy a kívánt kész illetve félkész terméket létre tudjuk hozni. Hideg- préselés során, ahogy a neve is elárulja, a nyersanyag hőmérséklete az átkristályosodási hőmérséklet-érték alatt marad megmunkálás közben.

A képlékeny alakítás fogalmában számtalan megmunkálási technológiáról beszélhetünk, amelyeknek az egyik legfontosabb jellemzőjük az, hogy a megmunkálás során nem keletkezik forgács. Ezért nevezik ezen megmunkálási technológiákat forgács nélküli megmunkálásnak is. 


\section{Vágás, lyukasztás}

A továbbiakban a hidegalakítási technológiák sajátos és igen elterjedt formájával, a lyukasztással illetve kivágással foglalkozunk. E technológia alkalmazása során a munkadarab alakját a kivágó illetve lyukasztószerszám úgynevezett aktív elemei (vágóbélyegek, lyukasztóbélyegek) határozzák meg.

Kivágáskor a lemezsávból kieső rész lesz a munkadarab, a sávmaradék meg a hulladék. Lyukasztáskor viszont a lemezsávból vagy már az előgyártmányból kieső rész lesz a hulladék.

A vágás során az anyagban három fázist figyelhetünk meg (1. ábra) [1]:

- A bélyeg behatol a munkadarab anyagába és rugalmasan deformálja.

- Az alakváltozás során fellépő feszültségek elérik az alakítási szilárdságot és az anyag képlékenyen alakul.

- Kimerül az anyag alakváltozó képessége, nyírási repedések keletkeznek, majd a vágóbélyeg körvonalán beszakad az anyag és a vágás befejeződik.

\section{Az anyaghíd szélessége}

Sávterv készítésekor (2. ábra) az egyes munkadarabok közt egy-egy hidat kell hagyni, amely szerepe egyrészt a vágás biztonságossá tétele (ne forduljon be a lemez a vágórésbe) másrészt a hulladék esetleg a munkadarab - továbbtaszítása a szerszám vágólap-furatában. Az anyaghíd mérete a valóságban jelentősen befolyásolhatja a bélyegben a feszültségeloszlást, akár a munkadarab vágott felületének a minőségét. Jelen tanulmányban az anyagpalló szélességének hatását is figyeljük.
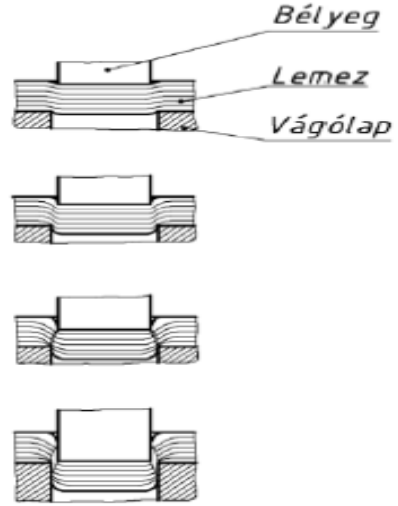

1. ábra. A kivágás-lyukasztás jellegzetes képlékenyalakitási fázisai

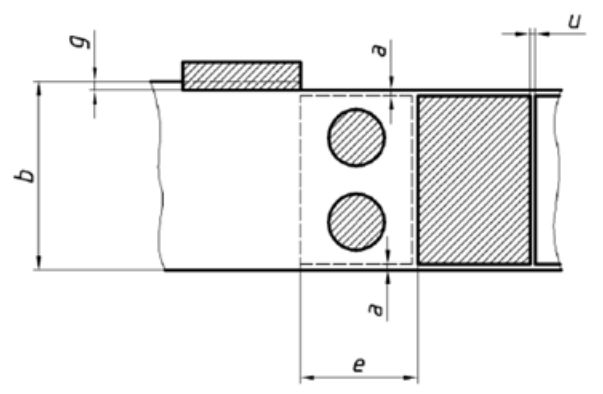

1. ábra. Az anyaghid

\section{A Levágó szerszám lekerekítési sugarának tanulmányozása}

Tökéletesen éles sarkot kivágással illetve lyukasztással nem lehet előállítani. Ennek oka az, hogy megmunkálás során az éles sarok jelenléte egy nemkívánatos, igen intenzív erőkoncentráció- zónát hoz létre a vágószerszámban. Ezért a vágóbélyeg sarkait lekerekítéssel kell tervezni és kivitelezni. A szakirodalom szerint [2] $90^{\circ}$-os bélyegsarok lekerekítésére általában a lemezvastagság 10\%-át javasolják, mint ahogy azt a 3. ábrán szemléltetett diagramon láthatjuk, amelyröl lekerekítési sugár olvasható le a lemezvastagság függvényében [2].

A minimális sarok- lekerekítési sugarat 


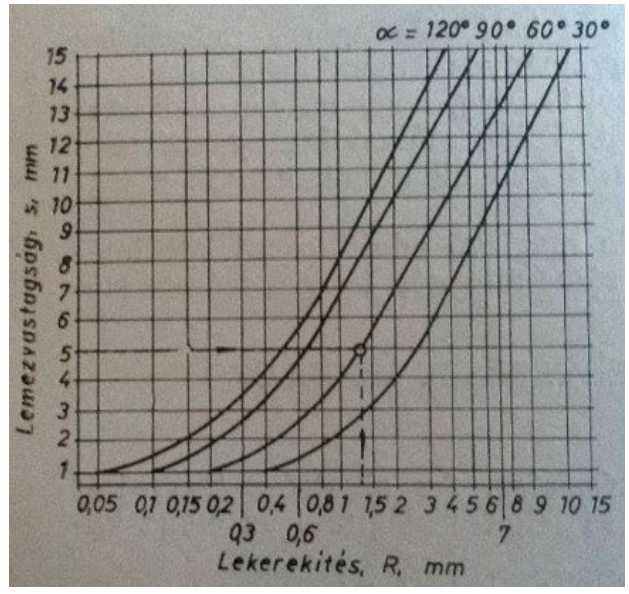

2. ábra. Sarok-lekerekités a lemezvastagság függvényében

az Autocad Inventor Stress Analyzis [3] szoftver segítségével kerestem. Az Inventor szoftver segítségével modellezett vágóbélyeg saroksugarát paraméterként kezeljük. Ennek a sugárnak függvényében figyeljük a bélyeg terhelésekor a sarkokban fellépő feszültségeket.

A testmodellhez az X210Cr12 típusú szerszámacélt rendeltem, melynek föbb, hidegalakítási szempontokat befolyásoló jellemzői a következők: folyáshatár (500$550 \mathrm{MPa})$, szakítószilárdság (750-880 MPa) Annak érdekében, hogy a bélyegre ható erőket vizsgáljuk, a bélyeg vágósíkját lekötjük, mintha egy alakíthatatlan lemezbe nyomná bele a prés müködés közben. A bélyeget akkora erővel terheljük, amely egy $2 \mathrm{~mm}$ es vastagságú lemez átvágásához szükséges. A terhelési diagramot a 4. ábrán szemléltettük. Ebből leolvasható a sarkokban fellépő feszültség maximális értéke, a lekerekítési sugár függvényében.

A vizsgálat során 12 saroklekerekítésértéket vettünk fel, a $0,1 \mathrm{~mm}-2 \mathrm{~mm}$ intervallumban. $\mathrm{Az}$ adatokat Microsoft Excel táblázatba rendezzük és ezen program segítségével rajzoltjuk fel az a 5. ábrán szemléltetett diagramot.

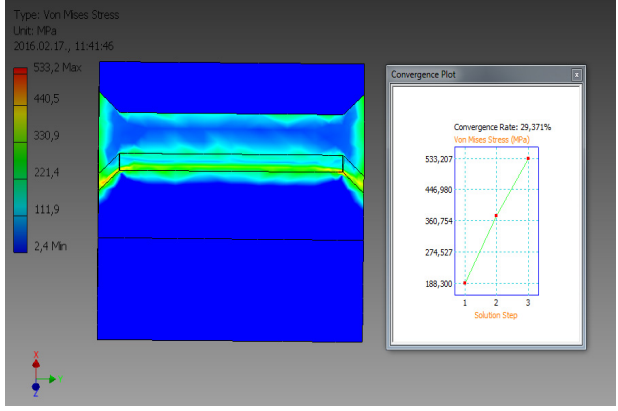

3. ábra. Minimális sarok kerekités vizsgálata Inventor segitségével

\section{Táblázat}

\begin{tabular}{|c|c|}
\hline $\begin{array}{c}\text { Lekerekítési sugár } \\
{[\mathrm{mm}]}\end{array}$ & $\begin{array}{c}\text { Max. terhe- } \\
\text { lés }\left[\mathrm{N} / \mathrm{mm}^{2}\right]\end{array}$ \\
\hline 0 & 426,8 \\
\hline 0,1 & 615,881 \\
\hline 0,2 & 533,207 \\
\hline 0,3 & 525,121 \\
\hline 0,4 & 462,557 \\
\hline 0,5 & 473,155 \\
\hline 0,6 & 464,76 \\
\hline 0,7 & 431,578 \\
\hline 0,8 & 444,871 \\
\hline 0,9 & 446,449 \\
\hline 1 & 423,731 \\
\hline 1,5 & 441,533 \\
\hline 2 & 441,584 \\
\hline
\end{tabular}

\section{A pallószélesség hatásának vizsgá- lata}

Pallószélesség vizsgálatakor 3mm értéktől vizsgáltuk a bélyeg teherbírását üzemi terhelés alatt és figyeltük a fellépő feszültségeket (6. ábra). A modelles vizsgálat alapján az derül ki, hogy a $7 \mathrm{~mm}$ es pallószélesség szükséges minimálisan ahhoz, hogy a vágóbélyeg megfeleljen a terhelésnek. 


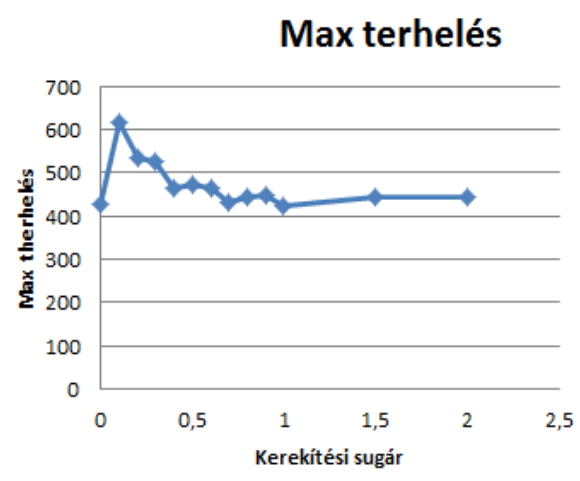

4. ábra. Terhelési diagram a sarokkerekitések függvényében

A terhelési diagram a 7. ábrán található.

\section{Következtetések}

Az 5. ábrán feltüntetett diagramból leolvasható, hogy a modell során figyelembe vett $2 \mathrm{~mm}$-es anyagvastagság számára a 0,7 mm-es lekerekítés a legoptimálisabb a feszültségeloszlást eredményezi. Ha ezt az értéket összevetjük a kísérleti úton létrehozott diagrammal (3. ábra) belátható, hogy sokkal nagyobb, mint a diagramból kiolvasható $\approx 0,24 \mathrm{~mm}$. Az eredmény azzal magyarázható, hogy a bélyeg terhelése során masszív anyagtömeget tekintettünk. erők eloszlását figyelembe véve.

A vizsgálat során kapott közel 7 mm-es pallószélesség is a szakirodalomban közölt érték [4] közel háromszorosa.

Következtetésként leszögezhetö, hogy a modell további finomításra szorul. Ezt a következőkben a valós anyag illetve a vágólap- modellek beiktatásával próbáljuk elérni.

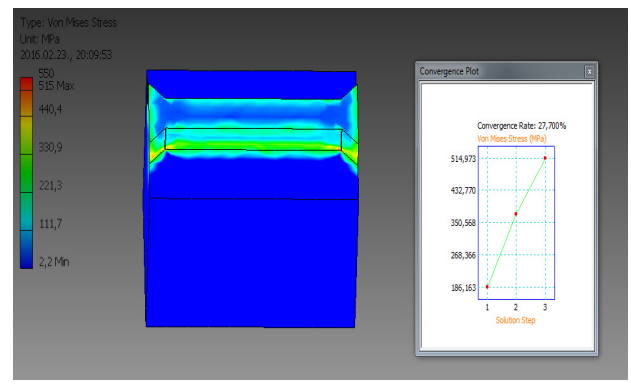

5. ábra. Pallószélesség vizsgálata Autodesk Inventor segitségével

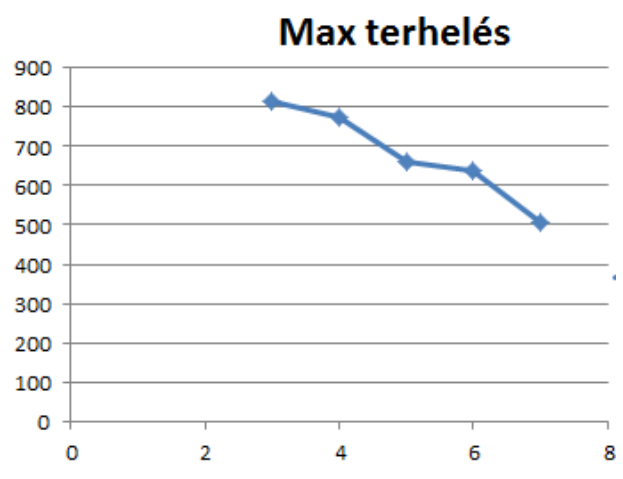

6. ábra. Terhelési diagram a pallószélesség függvényében

\section{Szakirodalmi hivatkozások:}

[1] Danyi, J., Végvári, F.: Lemezmegmunkálás. GAMF, Kecskemét, 2011.

[2] Gans, A.: Forgácsmentes hidegmegmunkálás. Népszava Szakszervezetek Országos Tanácsa Lap- és Könyvkiadóvállalata, Budapest, 1951.

[3] Tolvaly-Roşca, F.: A számitógépes tervezés alapjai. Autolisp és Autodesk inventor alapismeretek. EME, 2012.

[4] Iliescu, C.: Tehnologia presării la rece. E.D.P., București, 1985. 